\title{
Interlaboratory Comparison of Trace Metal Analyses by Graphite Furnace (Flameless) Atomic Absorption Spectroscopy
}

\author{
R. R. Turner \\ S. E. Lindberg
}




\section{DISCLAIMER}

This report was prepared as an account of work sponsored by an agency of the United States Government. Neither the United States Government nor any agency Thereof, nor any of their employees, makes any warranty, express or implied, or assumes any legal liability or responsibility for the accuracy, completeness, or usefulness of any information, apparatus, product, or process disclosed, or represents that its use would not infringe privately owned rights. Reference herein to any specific commercial product, process, or service by trade name, trademark, manufacturer, or otherwise does not necessarily constitute or imply its endorsement, recommendation, or favoring by the United States Government or any agency thereof. The views and opinions of authors expressed herein do not necessarily state or reflect those of the United States Government or any agency thereof. 


\section{DISCLAIMER}

Portions of this document may be illegible in electronic image products. Images are produced from the best available original document. 
Printed in the United States of America: Available from National Technical Information Service

U.S. Department of Commerce

5285 Port Royal Road, Springfield, Virginia 22161

Price: Printed Copy $\$ 4.00$; Microfiche $\$ 2.25$

This report was prepared as an account of work sponsored by the United States Government. Neither the United States nor the Energy Research and Development Administration/United States Nuclear Regulatory Commission, nor any of their employees, nor any of their contractors, subcontractors, or their employees, makes any warranty, express or implied, or assumes any legal liability or responsibility for the accuracy, completeness or usefulness of any information, apparatus, product or process disclosed, or represents that its use would not infringe privately owned rights. 
ORNL/TM-5422

Contract No. W-7405-eng-26

INTERLABORATORY COMPARISON OF TRACE METAL ANALYSES BY GRAPHITE FURNACE (FLAMELESS) ATOMIC ABSORPTION SPECTROSCOPY

R. R. Turner and S. E. Lindberg

Environmental Sciences Division

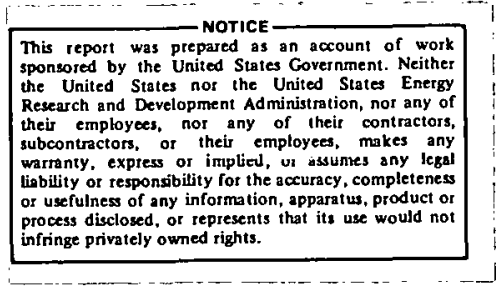

Publication No. 879, Environmental Sciences Division

JULY 1976

OAK RIOGE NATIONAL LABORATORY

Oak Ridge, Tennessee 37830

operated by

UNION CARBIDE CORPORATION

for the

ENERGY RESEARCH AND DEVELOPMENT ADMINISTRATION 


\section{THIS PAGE}

\section{WAS INTENTIONALLY \\ LEFT BLANK}




\section{ABSTRACT}

TURNER, R. R., and S. E. LINDBERG. 1976. Interlaboratory comparison of trace metal analyses by graphite furnace (flameless) atomic absorption spectroscopy. ORNL/TM-5422. Oak Ridge National Laboratory, Oak Ridge, Tennessee. 20 pp.

The analytical sensitivity, precision, and accuracy of trace metal $(\mathrm{Pb}, \mathrm{Cd}, \mathrm{Cr}, \mathrm{Cu}, \mathrm{Fe}$, and $\mathrm{Mn}$ ) analyses on aqueous samples performed at ORNL using a flameless graphite furnace atomic absorption system was evaluated in comparison to analyses performed by three independent laboratories using similar systems. All laboratories analyzed replicates of the same five samples which included twice distilled water, two U.S. EPA reference trace metal standards and two natural water samples (rain and stream water). Although the laboratories were informed of the range of concentrations to be expected none were informed of the nature of the samples to be analyzed.

Analyses performed at ORNL were generally superior with respect to sensitivity and precision to those performed elsewhere. Approximate limits of detection, as indicated by analyses of the distilled water performed at ORNL, were close to those claimed by the instrument manufacturer. No one laboratory reported values which were consistently more accurate than those reported by the others and from some laboratories replicate values for the reference standards varied considerably. The best overall combination of precision and accuracy on the reference sample with the lowest concentrations $(0.2-2.8 \mu \mathrm{g} / 1)$ was exhibited by ORNL. In contrast, ORNL exhibited the poorest combination of precision and accuracy on the reference sample with the highest concentration $(2-28 \mu \mathrm{g} / 1)$. This reversal occurred largely because of apparent inaccuracy of lead analyses performed by ORNL on one of the reference samples. However, subsequent analyses of new reference standards by ORNL indicated accurate values for lead.

Results reported for the natural water samples suggested that although the flameless atomic absorption method is sufficiently sensitive to quantitatively detect concentrations of selected trace metals in natural water without preconcentration procedures, the method may be too imprecise in some cases if small natural variations (on the order of $20-50 \%$ ) in concentration are to be detected. 


\section{THIS PAGE WAS INTENTIONALLY LEFT BLANK}


TABLE OF CONTENTS

$\underline{\text { Page }}$

ABSTRACT ............................ $i$. .

INTRODUCTION ............................ 1

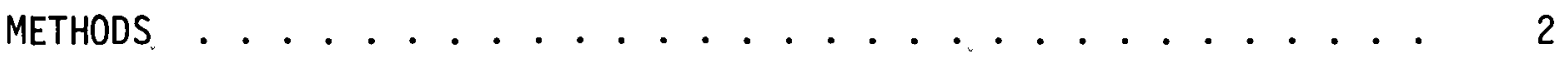

RESULTS AND DISCUSSION . . . . . . . . . . . . . 4

Sensitivity ...................... 4

Accuracy ................ . . . 10

Analytical Precision on Natural Water Samples....... 13

CONCLUSIONS ....................... 15

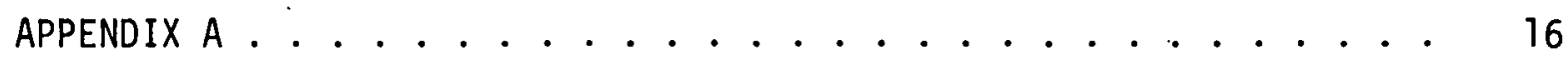

APPENDIX B ............................... 17

APPENDIX C................................ 18

APPENDIX D.................................. 19

APPENDIX E.............................. 20 
THIS PAGE

WAS INTENTIONALLY

LEFT BLANK 
Figure 1. Average and range of trace metal concentrations reported by each laboratory for double-distilled water with $1.5 \mathrm{ml}$ U1trex $\mathrm{HNO}_{3}$ per liter. Also shown are relative detection limits given by Perkin-Elmer Corp. for each metal . . .

Figure 2. Average and range of trace metal concentrations reported by each laboratory for the low EPA reference standard and the information concentration for each metal ......

Figure 3. Average and range of trace metal concentrations reported by each laboratory for the high EPA reference standard and the information concentration for each metal ... 7

Figure 4. Average and range of trace metal concentrations reported by each laboratory for precipitation collected on walker Branch Watershed . . . . . . . . . . 8

Figure 5. Average and range of trace metal concentrations reported by each laboratory for filtered stream water from the West Fork of Walker Branch Watershed .........

Figure 6. Interlaboratory and intralaboratory coefficients of variation for trace metal concentrations in precipitation and stream samples collected on Walker Branch Watershed ............... 


\section{THIS PAGE}

\section{WAS INTENTIONALLY \\ LEFT BLANK}




\section{LIST OF TABLES}

Page

Table 1. Comparison of analytical methodologies......... . 3

Table 2. Statistic defined as the square root of the sum of squares of deviations of individual concentrations

from EPA reference values ........... 12 


\section{INTRODUCTION}

In January 1975 the Environmental Sciences Division (ESD) acquired a Perkin-Elmer Model 503 Atomic Absorption Spectrophotometer with a Model 2100 Heated Graphite Atomizer system which is now being operated by Analytical Chemistry Division (ACD) personnel in the Environmental Analysis Laboratory. The very high sensitivity (sub-ppb for many trace elements), the small sample volume requirements (10 to 100 microliters) and semiautomatic features of the analytical procedure were major factors in the decision to acquire this instrument for trace element research within the ESD. In our particular studies of rainfall inputs and streamflow outputs of trace metals from Walker Branch Watershed (WBW) this instrument appeared to offer a solution to longstanding difficulties in the analysis of dissolved trace elements in relatively unpolluted natural waters by not requiring preconcentration procedures which have an inherent potential for contamination and/or losses of trace elements.

To evaluate the instrument for its applicability to our projects we conducted a small quality assurance experiment involving ORNL and three independent laboratories. We were also interested in evaluating the competitiveness of ACD's costs and turnaround time for trace element analyses using this instrument with other laboratories using the same or closely related instruments. Finally, and most importantly in our view, we needed to establish early in our current studies that our overall analytical precision, including sample handling and storage prior to submission for analyses, is sufficiently high for us to distinguish true variability in the environments of study. The low concentration levels expected in our aqueous samples required "non-routine" methods and each outside laboratory was informed of the "expected" range of concentrations and requested to use graphite furnace atomic absorption spectroscopy. None of the laboratories, including ORNL, was informed that they were being tested with replicate reference samples in the hope that reported results would more truly reflect the analytical sensitivity, precision and accuracy offered by each laboratory.

With the above objectives in mind we assembled a set of aqueous samples prepared in triplicate representing (1) reference standards prepared in concentrated form by the U.S. Environmental Protection Agency and diluted by us, (2) typical rain and streamwater samples collected on Walker Branch Watershed (WBW) and (3) distilled water from our laboratory supply. It was anticipated that all of these would help us evaluate analytical precision, that the reference standards would help us evaluate accuracy and that the distilled water samples would help us estimate practical limits of quantitative detection for aqueous samples. The rain and streamwater samples were subjected to our normal handling and preservation procedures but were stored somewhat longer than usual prior to submission for analysis. The analytical results reported here for these samples probably best represent our overall precision in measuring trace element concentrations on WBW. Although we frequently measure concentrations of other trace metals, those included in this experiment were restricted to copper, lead, manganese, zinc, chromium and cadmium. 


\section{METHODS}

The sample set consisted of five separate aqueous samples:

(1) A streamwater sample (hereinafter referred to as stream sample) collected in the WBW west stream on 3/13/75, filtered within 2 hours of collection through a $0.4 \mu$ Nuclepore membrane, and preserved in a 11 iter polyethylene bottle with the addition of $5 \mathrm{ml}$ of reagent grade $16 \mathrm{~N} \mathrm{HNO}_{3}$ per liter of sample;

(2) A precipitation sample (rainwater sample) collected in WBW at rain gauge $\# 1$ in a Wong sampler from $3 / 6 / 75-3 / 13 / 75$ and preserved as above; although the original sample was not filtered, care was taken to ensure that particulate matter had settled out before subsampling was done;

(3) A double-distilled water sample prepared on $7 / 10 / 75$ and preserved in a 2 liter Pyrex glass bottle with the addition of $1.5 \mathrm{ml}$ of U1trex $16 \mathrm{~N}$ $\mathrm{HNO}_{3}$ per liter of sample;

(4) A U.S. Environmental Protection Agency aqueous trace metal reference sample \#1 (high reference standard) prepared as prescribed in literature provided by EPA using the acid-preserved, double-distilled water described above as the diluent;

(5) The same U.S. EPA reference sample described in (4) but diluted by $1 / 10$ or 1 to 1.0 using the acid-preserved double-distilled water as the diluent (hereinafter referred to as low reference standard).

On $7 / 10 / 75$ all samples were separated into 12 individual $75 \mathrm{ml}$ aliquots and placed in clean $125 \mathrm{ml}$ polyethylene bottles. These bottles were precleaned as follows: thorough rinsing with tap water followed by single-distilled water and double-distilled water, then leaching with $2 \mathrm{~N}$ $\mathrm{HNO}_{3}$ for 12 hours in a reciprocating shaker, followed by rinsing with double-distilled water for 12 hours in a reciprocating shaker. These 12 replicates for each sample were then separated into 4 sets of 3 replicates each, numbered randomly, and submitted to four individual analytical laboratories.

The laboratories are herein referred to by number but consisted of the following: the ORNL Analytical Chemistry Division Environmental Analysis Laboratory (M. Ferguson, director; K. Talbott, atomic absorption analyst) which is designated hereafter as ORNL-EAL; two private analytical service laboratories, and one university-associated research center. These latter three were randomly assigned numbers 2, 3 and 4 . The pertinent information regarding instruments, analytical techniques, relative costs, and turnaround times are summarized in Table 1 . Relative costs for ORNL-EAL are based on an annual sample load while costs for the private laboratories are based on the single sample set of 90 analyses which comprised this test. Discussions with the private labs revealed that the price per analysis would decrease if based on a commitment of a given number of analyses over a longer time period ( $\sim 1$ year). 
Table 1. Comparison of analytical methodologies and related information for the four laboratories tested.

\begin{tabular}{|c|c|c|c|c|}
\hline \multirow[b]{2}{*}{ Parameter } & \multicolumn{4}{|c|}{ LAB \# } \\
\hline & $\stackrel{1}{1} \cdot($ ORNL-EAL) & 2 & 3 & 4 \\
\hline Ins trument & $\begin{array}{l}\text { Perkin Elmer AAS Model } \\
503 \text { with Hea-ed Graphite } \\
\text { Atomizer Model } 2100\end{array}$ & $\begin{array}{l}\text { Perkin Elmer AAS } \\
\text { Model } 360 \text { with } \\
\text { Heated Graphite } \\
\text { Atomizer Model } \\
2100\end{array}$ & $\begin{array}{l}\text { Perkin Elmer AAS } \\
\text { Model } 503 \text { with } \\
\text { Heated Graphi te } \\
\text { Atomizer Model } \\
2100\end{array}$ & $\begin{array}{l}\text { Perkin Elmer AAS } \\
\text { Model } 403 \text { with Heated } \\
\text { Graphite Atomizer } \\
\text { Model } 2100\end{array}$ \\
\hline Technique & $\begin{array}{l}\text { Method of Standard } \\
\text { Additions, each sample } \\
\text { injected in duplicate }\end{array}$ & $\begin{array}{l}\text { Method of Standard } \\
\text { Curve, each sample } \\
\text { injected in dupli- } \\
\text { cate }\end{array}$ & $\begin{array}{l}\text { Method of Standard } \\
\text { Curve, each sample } \\
\text { injected in tripli- } \\
\text { cate; checked with } \\
\text { reference standards }\end{array}$ & $\begin{array}{l}\text { Method of Standard } \\
\text { Additions, } 10 \% \text { of } \\
\text { samples are injected } \\
\text { in duplicate }\end{array}$ \\
\hline $\begin{array}{l}\text { Turnaround Time: } \\
\text { Shipping requested - } \\
\text { Recieved by labora- }\end{array}$ & $\begin{array}{l}56 \text { days } \\
7 / 10,75\end{array}$ & $\begin{array}{l}14 \text { days } \\
7 / 10 / 75\end{array}$ & $\begin{array}{l}43 \text { days } \\
7 / 10 / 75\end{array}$ & $\begin{array}{l}32 \text { days } \\
7 / 10 / 75\end{array}$ \\
\hline $\begin{array}{l}\text { tory - } \\
\text { Results transmitted - }\end{array}$ & $\begin{array}{l}7 / 10 / 75 \\
9 / 4 / 75\end{array}$ & $\begin{array}{l}8 / 8 / 75 \\
8 / 22 / 75\end{array}$ & $\begin{array}{l}8 / 13 / 75 \\
9 / 25 / 75\end{array}$ & $\begin{array}{l}8 / 4 / 75 \\
9 / 5 / 75\end{array}$ \\
\hline $\begin{array}{l}\text { Cost per Analysis } \\
\text { Relative to Lab } \# 1\end{array}$ & 1.0 & 0.7 & 1.4 & 2.9 \\
\hline
\end{tabular}

${ }^{1}$ An analysis is one trace metal determination on one sample. 
RESULTS AND DISCUSSION

Concentrations of the six trace elements reported by each laboratory for each sample are given in Appendices $A$ through $E$. The average and range of concentrations reported by each laboratory for each sample are also shown graphically in Figures 1 through 5 along with either the interlaboratory average (distilled water, stream and rain samples) or the concentration value given by the U.S. EPA (reference samples). Concentrations reported as "less than" by any laboratory were construed as being the practical lower limit of detection for a given element and presented some problems, particularly with respect to blank corrections. One can either ignore the "less than" prefix and assume that the reported value is the actual concentration (e.g., $<0.5$ equal to 0.5 ) or assume that the actual concentration is zero $(<0.5$ equal to 0.0$)$. Neither of these options is very realistic. One solution is to compare results using both assumptions and observe how each assumption changes the conclusions. Where blank corrections were deemed absolutely necessary, as with the reference samples, we applied both assumptions in calculating the statistics presented subsequently. In all other calculations and plots the "less than" prefix was ignored (i.e., the reported value was assumed to be the actual concentration).

Concentrations of each trace element reported by each laboratory for our $\mathrm{HNO}_{3}$ preserved double-distilled water were assumed to represent blank values for the reference standards, since that solution was used as the diluent in the preparation of the EPA standards, and were subtracted prior to analysis of the concentration data. No blank corrections were made to the distilled water, rain and stream data, as we had not determined blanks for the concentrated $\mathrm{HNO}_{3}$ used as a preservative in these samples.

\section{Sensitivity}

Analytical sensitivity is ordinarily defined as the mass, or concentration, of an element that produces an instrument response which is distinct from instrument noise. In flameless atomic absorption spectroscopy the mass of an element deposited on the atomizer can be varied considerably by varying the volume of aqueous sample injected. Under normal, programcontrolled, operating conditions 100 microliters is the maximum injection volume for the Perkin-Elmer system used by all laboratories in this study. Thus sensitivity is determined on this system by the lowest concentration that can be detected unambiguously in a 100 microliter sample. Since we could not provide solutions with lower trace metal concentrations than those in our twice distilled water and did not wish to divulge our purpose to the participating laboratories by requesting calibration curves or other specific analytical details, our evaluation of sensitivity is of necessity operational. As used here sensitivity, or approximate limit of detection, is defined as the lowest concentration value reported by a laboratory for a particular element. "Less than" values, where reported, were interpreted to be actual lower limits of detection for the reporting laboratory. Where actual concentrations were reported for a distilled water constituent the 


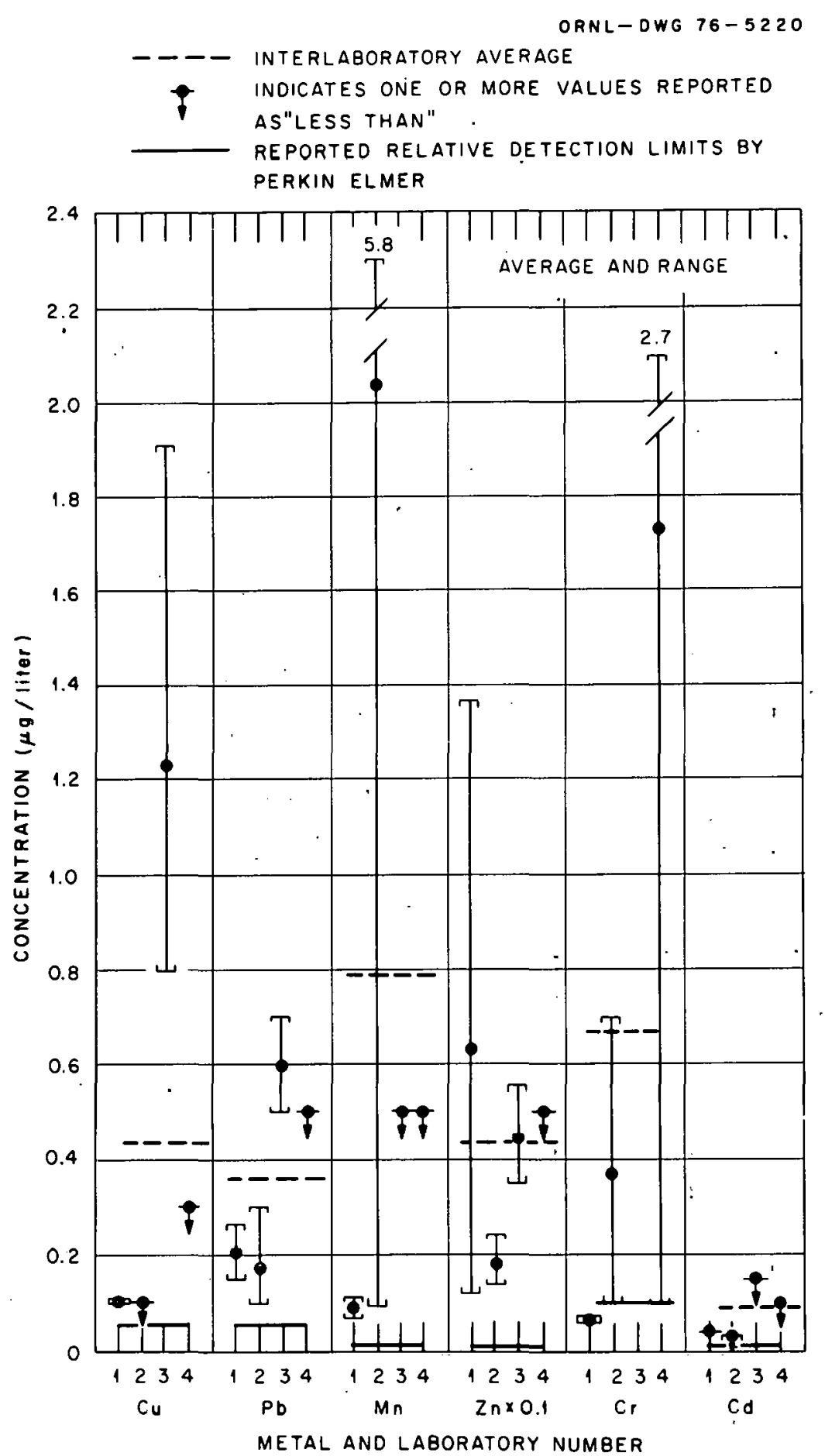

Fig. 1. Average and range of trace metal concentrations reported by each laboratory for double-distilled water with $1.5 \mathrm{ml}$ Ul trex $\mathrm{HNO}_{3}$ per liter. Also shown are relative detection limits given by PerkinElmer Corp. for each metal. 


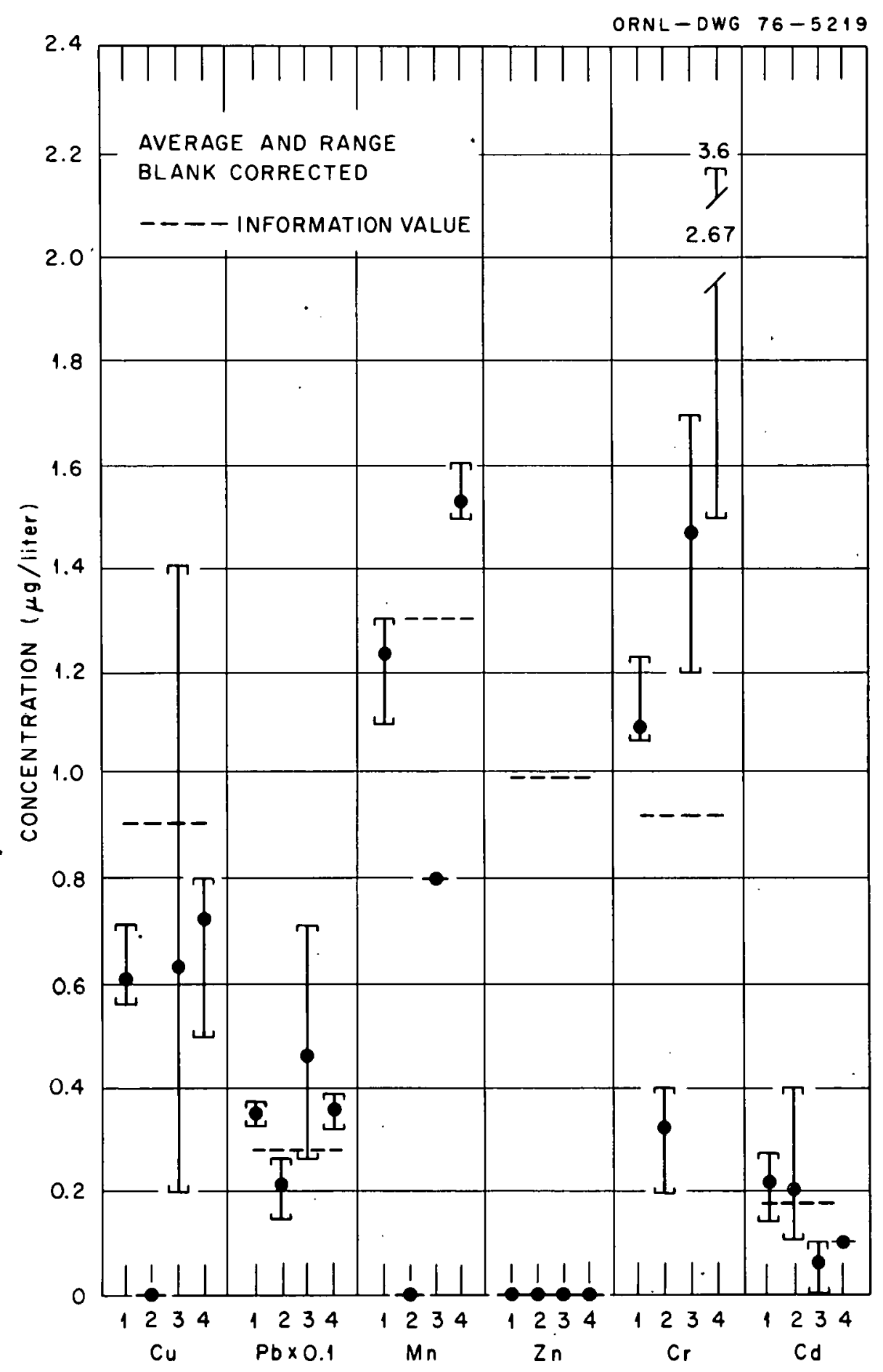

METAL AND LABORATORY NUMBER

Fig. 2. Average and range of trace metal concentrations reported by each laboratory for the low EPA reference standard and the information concentration for each metal. 


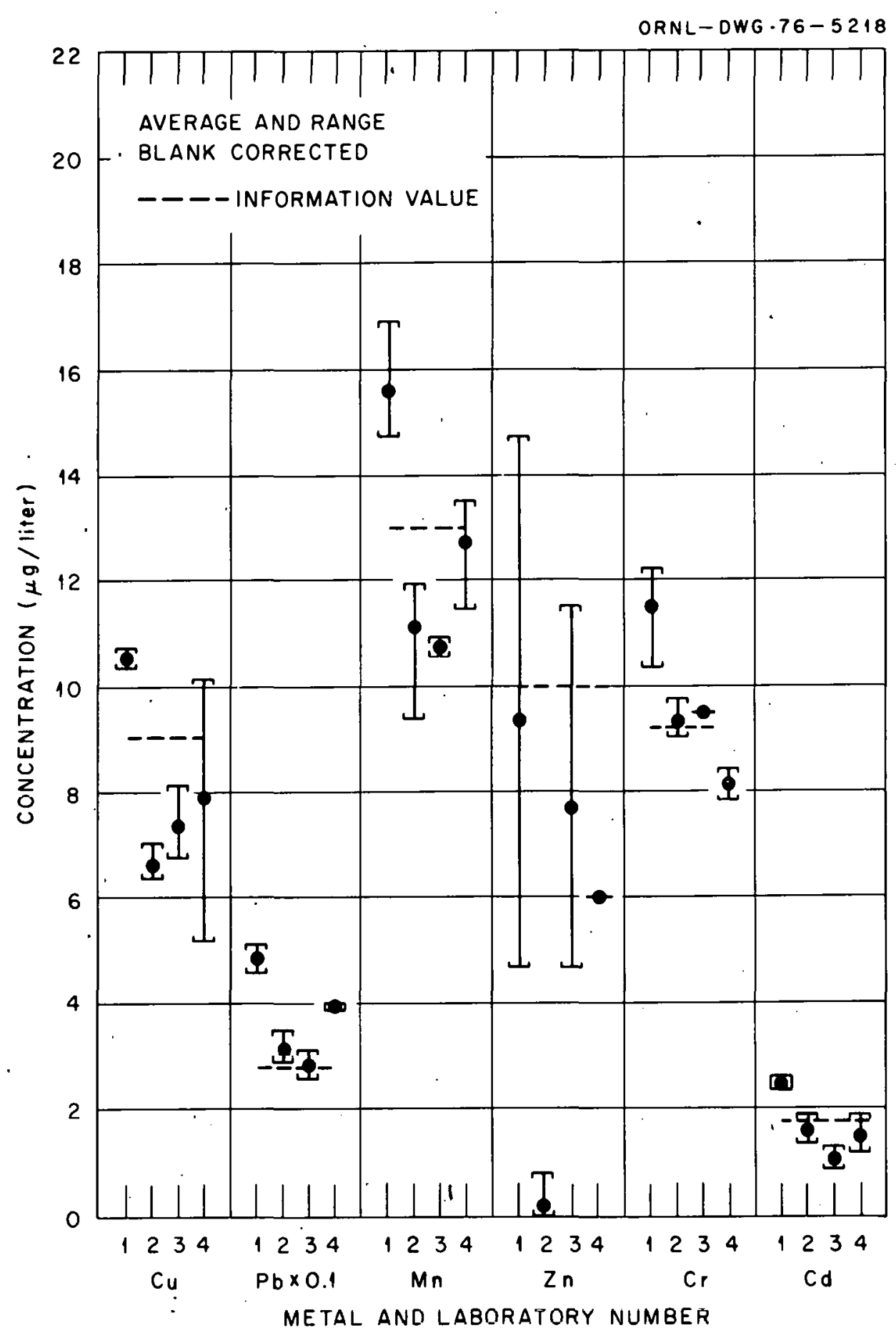

Fig. 3. Average and range of trace metal concentrations reported by each laboratory for the high EPA reference standard and the information concentration for each metal. 


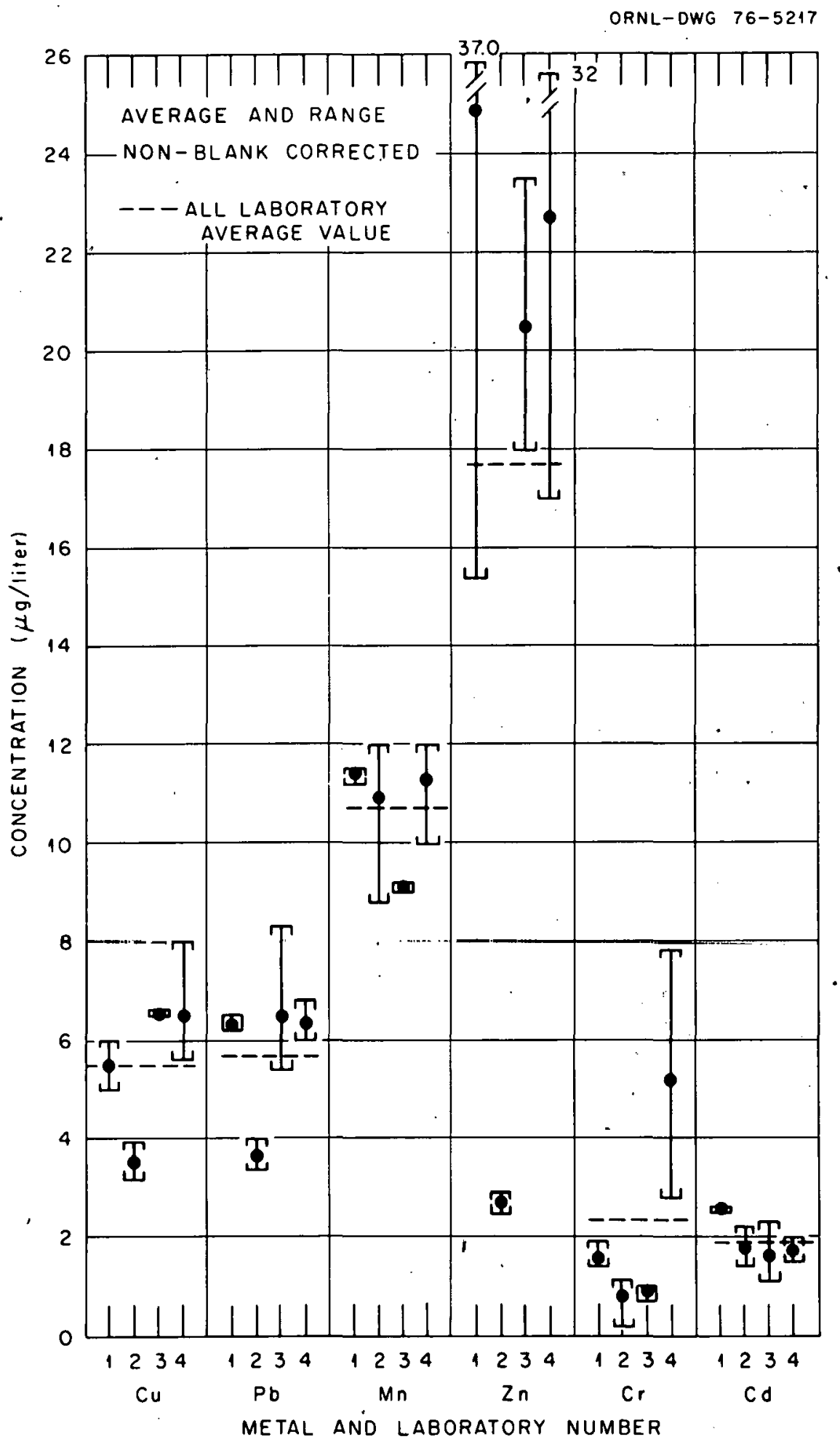

Fig. 4. Average and range of trace metal concentrations reported by each laboratory for precipitation collected on Walker Branch Watershed. 


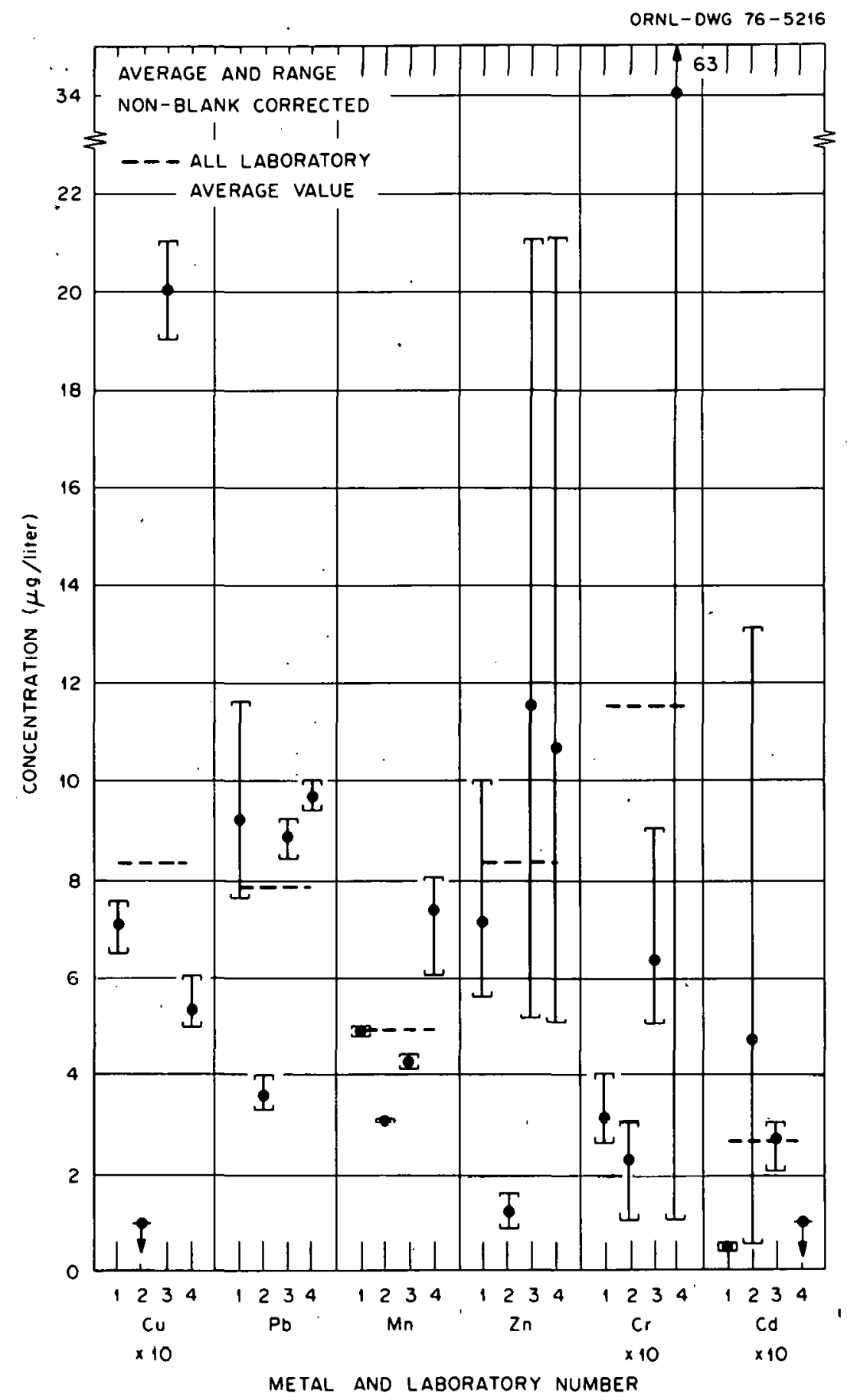

Fig. 5. Average and range of trace metal concentrations reported by each laboratory for filtered stream water from the West Fork of Walker Branch Watershed. 
actual limit of detection was obviously equal to, or better than, the lowest reported value for the constituent.

Based on comparison of results reported for the distilled water plus $\mathrm{HNO}_{3}$ (Appendix A, Figure 1) ORNL-EAL appeared to offer the best overail approximate detection limits which were in fact close to those claimed by the manufacturer. All of the laboratories except ORNL-EAL reported "less than" values for at least one constituent in the distilled water but all achieved sub- $\mu \mathrm{g} / 1$ (ppb) levels of detection for all elements except zinc. Except for zinc, ORNL-EAL also appeared to have the best analytical precision for the distilled water samples although the abundance of "less than" values reported by the other laboratories precludes any rigorous comparison.

\section{Accuracy}

According to the U.S. EPA the "information" concentrations of each trace element in their diluted reference samples are based on accurately weighed amounts of spectrographically pure metals or metal compounds dissolved in redistilled nitric acid. These reference samples are thoroughly checked and verified for stability and accuracy of the concentrates by repeated analyses over a period of months before the U.S. EPA releases the samples for use in analytical quality control testing. The U.S. EPA has also conducted analytical round-robins involving many independent laboratories using their aqueous reference samples but to date have not published the results. For lack of a better value we must accept the "information" concentration values given by the U.S. EPA as true values in the following comparison of analytical accuracy.

Figures 2 and 3 compare the results reported by each laboratory for each trace element fur the high and low referencc samplcs with the information values given by the U.S. EPA. It is readily apparent from these figures that no one laboratory is consistently more accurate than another and that for some elements and laboratories replicate analyses vary considerably. In an effort to be as objective as possible we have devised a simple statistic which can be used to select the laboratory offering the best combination of accuracy and precision for each trace element based on analyses reported for each reference sample. Clearly, with the data set limited to triplicate analyses by each lab for each sample we did not feel confident in eliminating outliers (extreme data values). The statistic is the square root of the sum of the squares (ss) of deviations of reported concentrations from the information value, or

$$
\sqrt{\sum_{i=1}^{j}\left(X_{i}-Y\right)^{2}},
$$

where $X_{i}$ represents results of the replicate analyses and $Y$ is the information value. The statistic will assume a minimum value when reported 
replicate values exhibit the following characteristics: (1) low variability (high precision) and (2) proximity to the information value (good accuracy). Reported replicate values which average close to the information value but deviate individually from the information value will obviously result in a larger value for this statistic than if the analyses were also highly precise. The statistic will be meaningless when blank concentrations equal or exceed reported concentrations for a reference sample. Such situations are designated by N.A. (not applicable) in Table 2 where the calculated statistic is summarized for the two reference samples.

Comparing the calculated statistic for samples which were blank corrected revealed ORNL-EAL offered the best or second best overall accuracy and precision for all elements studied in the EPA low reference sample (Table 2). However, for the high reference sample ORNL-EAL exhibited results in line with the other labs for only three elements ( $\mathrm{Cu}, \mathrm{Zn}$ and $\mathrm{Cd}$ ) while it exhibited the worst results for $\mathrm{Pb}, \mathrm{Mn}$ and $\mathrm{Cr}$. The effect of "less than" blank values being considered as equal to zero is not illustrated here since the use of this assumption had little effect on both the individual calculations and the relative ratings of the four laboratories, whether they reported "less than" values or not. Therefore, the lab to lab comparisons are based on the results obtained by ignoring "less than" prefixes, keeping in mind the obvious disadvantage of "less than" values. Under these assumptions the labs rank, in order of decreasing overall accuracy and precision, as follows:

$$
\begin{array}{ll}
\text { Iow EPA reference standard: } & 1 \simeq 4,2,3 \\
\text { high EPA reference standard: } & 3,4 \simeq 2,1
\end{array}
$$

The primary reason for the relatively low performance rating of ORNL-EAL on the high EPA standard was the poor accuracy (but good precision) achieved for the $\mathrm{Pb}$ standard (see Figure 3 ). Repeated analyses of these samples by ORNL-EAL revealed concentrations that are in line with those found earlier (still 36\% higher than the reported EPA value). A new set of EPA standards was recently obtained and sent to ORNL-EAL for further evaluation of $\mathrm{Pb}$ values in the 20-50 $\mathrm{\mu g} / 1$ range. Results of analyses on these standards indicated close agreement $( \pm 5 \%)$ with the U.S. EPA information value.

The element $Z n$ exhibited greatest interlaboratory coefficient of variations for 3 of the 5 sample sets analyzed (ranging from $\pm 60 \%$ to $200 \%$ of the mean). In addition, for each laboratory the poorest accuracy was for zinc in the low EPA standard. This is, in part, due to the overlap of reported values for the low EPA standard with blank values thus precluding any meaningful analysis of the results. We have suspected a $\mathrm{Zn}$ contamination problem for some time, but can only speculate on its source. Zinc is nearly a universal contaminant occurring in relatively high concentrations in numerous items used in our or any other laboratory (e.g., $\sim 5 \mu \mathrm{g} / 1$ in our double distilled water, $13 \mu \mathrm{g} / 1$ in reagent grade concentrated $\mathrm{HNO}_{3}, 40 \mathrm{ppm}$ in Nuclepore filters, $28 \mathrm{ppb}$ in polyethylene bottles, 
Table 2. Statistic defined as the square root of the sum of squares of deviations of individual concentrations from EPA reference values. The lowest value of the statistic is interpreted as indicating the best combination of precision and accuracy. All samples have been blank corrected. Where "less than" blank values occurred the reported values were assumed to be the actual values (i.e., $<0.5=0.5$ ).

\begin{tabular}{|c|c|c|c|c|c|c|}
\hline $\begin{array}{l}\text { Analytical } \\
\text { Laboratory }\end{array}$ & $\mathrm{Cu}$ & $\mathrm{Pb}$ & $M n$ & $2 n$ & $\mathrm{Cr}$ & $\mathrm{Cd}$ \\
\hline & & $\cdot$ & LOW EPA & REFEREN & & $\cdot$ \\
\hline \multirow[t]{2}{*}{$\begin{array}{l}1 \\
2 \\
3 \\
4\end{array}$} & $\begin{array}{l}0.55 \\
N A^{I} \\
0.99 \\
0.41\end{array}$ & $\begin{array}{l}1.4 \\
1.4 \\
4.4 \\
1.4\end{array}$ & $\begin{array}{l}0.20 \\
4.0 \\
0.87 \\
0.41\end{array}$ & $\begin{array}{l}\text { NA } \\
\text { NA } \\
52 \\
\text { NA }\end{array}$ & $\begin{array}{l}0.35 \\
1.2 \\
1.0 \\
3.4\end{array}$ & $\begin{array}{l}0.12 \\
0.21 \\
0.21 \\
0.14\end{array}$ \\
\hline & \multicolumn{6}{|c|}{ HIGH EPA REFERENCE } \\
\hline $\begin{array}{l}1 \\
2 \\
3 \\
4\end{array}$ & $\begin{array}{l}2.7 \\
4.2 \\
2.9 \\
4.2\end{array}$ & $\begin{array}{c}35 \\
7.2 \\
3.2 \\
19\end{array}$ & $\begin{array}{l}4.1 \\
3.9 \\
3.8 \\
1.7\end{array}$ & $\begin{array}{r}7.2 \\
17.1 \\
6.4 \\
\cdot \quad 6.9\end{array}$ & $\begin{array}{l}4.3 \\
0.52 \\
0.52 \\
1.2\end{array}$ & $\begin{array}{l}1.2 \\
0.57 \\
1.3 \\
0.73\end{array}$ \\
\hline
\end{tabular}

${ }^{1}$ Not applicable: (blank < measured value). 
$2 \times 10^{4} \mathrm{ppm}$ in neoprene rubber, and $1 \mathrm{ppm}$ in borosilicate glass;

Carpenter, 1968, Anal. Chem. 40: 1067). In addition, a recent paper reported observing $\mathrm{Zn}$ contamination in graphite furnace AAS analyses resulting from disposable auto-pipet tips. New tips when rinsed with $100 \mu l$ of $1 \% \mathrm{HCl}$ solutions were seen to release from $0.1-20 \mu \mathrm{g} / 1 \quad(\bar{x}=3.4 \mu \mathrm{g} / 1)$ which could significantly contaminate some natural samples. A simple cleaning procedure was suggested to reduce the contamination (three rinses in $1 \%$ Ultrex $\mathrm{HCl}$ followed by one double-distilled water rinse reduced subsequent leaching to $0-0.2 \mu \mathrm{g} / 1$; e.g., see Sommerfield et al., 1975, Atomic Abs. News 14: 31).

It is apparent from our results that a serious $\mathrm{Zn}$ contamination exists, at least for the sample set involved in this quality control test. The same case may also hold true for the elements $\mathrm{Cu}, \mathrm{Mn}$, and $\mathrm{Cr}$ (see Figure 1), although in each of these cases the contamination appears to occur for one individual laboratory and may actually relate to an analytical rather than a sample handling problem (e.g., Cu for lab \#3, Mn for lab \#2, Zn for all labs, and $\mathrm{Cr}$ for $\mathrm{lab} \# 4)$.

\section{Analytical Precision on Natural Water Samples}

Averages and ranges of trace element concentrations reported by each laboratory along with the interlaboratory averages for the WBW rain and streamwater samples are presented graphically in Figures 4 and 5 . In addition, Figure 6 displays intralaboratory and interlaboratory coefficients of variation for the rain and streamwater samples. Results for the rain samples indicate that the ORNL-EAL offers the best analytical precision for $\mathrm{Pb}(\mathrm{C} . \mathrm{V} .=3 \%), \mathrm{Mn}(\mathrm{C} . \mathrm{V} .=1 \%)$ and $\mathrm{Cd}(\mathrm{C} . \mathrm{V} .=2 \%)$ and second best for $\mathrm{Cu}(\mathrm{C} . V .=9 \%)$ and $\mathrm{Cr}(\mathrm{C} . V .=15 \%)$. Comparing intralaboratory averages $(N=3)$ with interlaboratory averages $(N=12)$ for each element in the rain sample reveals that the ORNL-EAL is in best agreement with the interlaboratory averages for $\mathrm{Cu}, \mathrm{Pb}$ and $\mathrm{Cr}$. Results for the streamwater samples indicate that the ORNL-EAL offers the best analytical precision for $\mathrm{Cr}$ (C.V. $=25 \%)$ and the second best precision for $\mathrm{Mn}(\mathrm{C} . \mathrm{V} .=3 \%), \mathrm{Zn}$ $(C . V .=28 \%)$ and $C d(C . V .=20 \%)$. Comparing the intralaboratory averages with the interlaboratory averages for each element in the streamwater sample reveals that the ORNL-EAL is in best agreement for $\mathrm{Cu}, \mathrm{Mn}$ and $\mathrm{Zn}$ and second best for $\mathrm{Pb}$ and $\mathrm{Cr}$. Thus the ORNL-EAL offers the best overall precision on the natural water samples and in most cases reported values are in line with those reported by the other laboratories.

Earlier studies on the natural variability in trace metal concentrations in WBW streamwater over a 15-month period have indicated that overall analytical precision for these metals should be less than $\pm 20 \%$ and preferably less than $\pm 10 \%$ if we are to be able to adequately detect natural variability in concentration. It would appear from this quality control experiment that the analytical precision for some elements (esp. $\mathrm{Zn}$ and $\mathrm{Cr}$ ) offered by even the best of the four laboratories tested is 

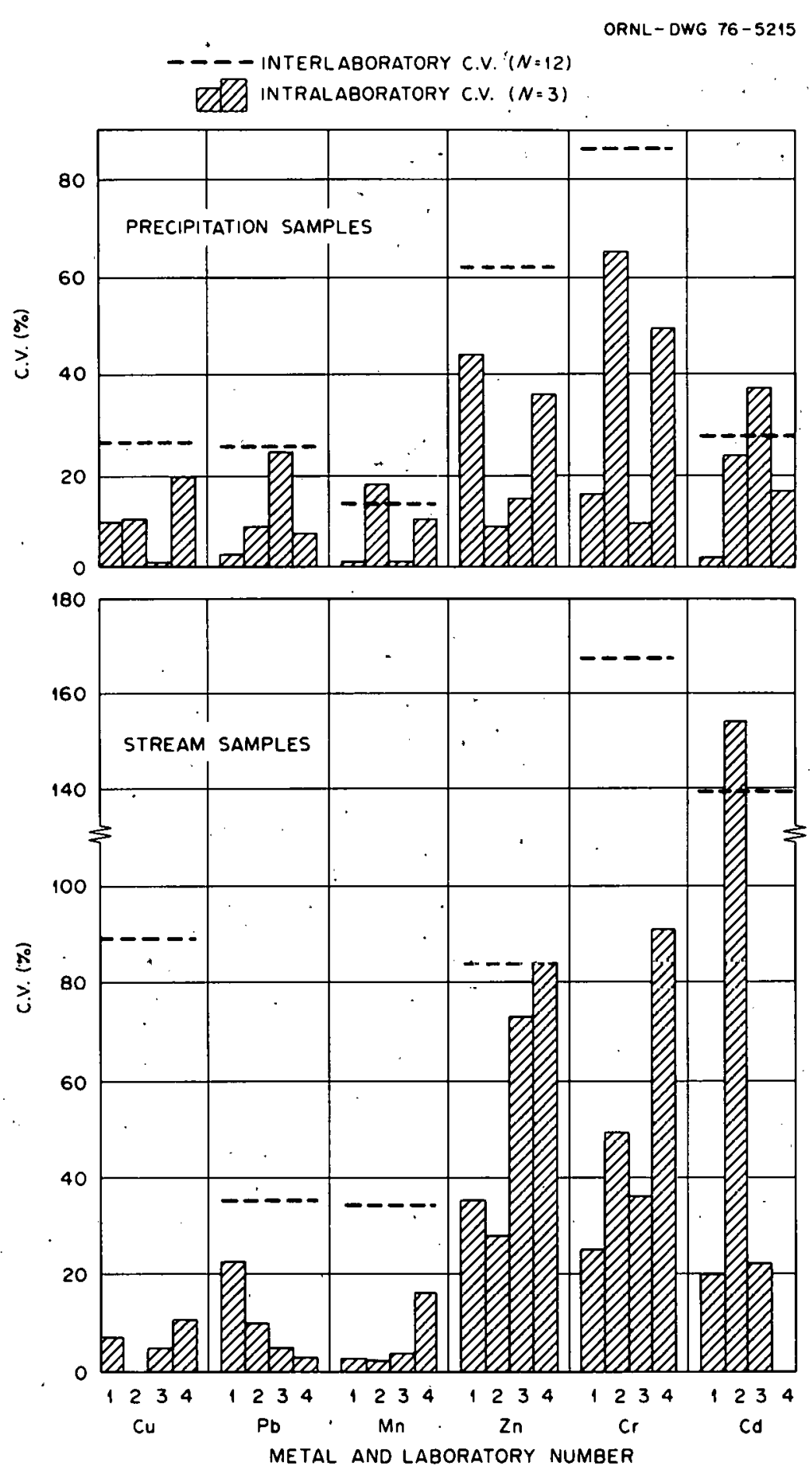

Fig. 6. Interlaboratory and intralaboratory coefficients of variation for trace metal concentrations in precipitation and stream samples collected on Walker Branch Watershed. 
marginal to poor in relation to the expected natural variability in dissolved concentrations in WBW streams. As indicated earlier we cannot be absolutely certain that this poor precision is entirely attributable to analytical procedures since contamination during handling and storage of replicate samples could also have contributed to imprecision. We plan further evaluations of the source of this imprecision in natural analyses.

\section{CONCLUSIONS}

1. Analyses of aqueous trace metal reference samples should be an integral part of environmental trace element studies.

2. "Less than" (<) values when reported are a disadvantage of any laboratory as they are difficult to interpret and make statistical evaluations tenuous.

3. Lab 1 (ORNL Environmental Analysis Laboratory) has the best sensitivity and best precision on very low $(<1 \mu \mathrm{g} / 1)$ concentration samples. Based on double-distilled water analyses approximate detection limits for Lab 1 are equal to or better than $0.10 \mu \mathrm{g} / 1$ for $\mathrm{Cu}, 0.15 \mu \mathrm{g} / \mathrm{l}$ for $\mathrm{Pb}, 0.07 \mu \mathrm{g} / \mathrm{l}$ for $\mathrm{Mn}, 1.2 \mu \mathrm{g} / 1$ for $\mathrm{Zn}, 0.07$ $\mu \mathrm{g} / 1$ for $\mathrm{Cr}$ and $0.04 \mu \mathrm{g} / 1$ for $\mathrm{Cd}$.

4. No one lab is consistently more accurate than another for all elements and for some replicate analyses vary considerably.

5. A simple statistic (square root of the sum of squares of deviations of measured from reported values) was devised to determine the best overall precision and accuracy on high $(2-28 \mu \mathrm{g} / 1)$ and low $(0.2-2.8$ $\mu \mathrm{g} / 1)$ reference samples. Using the statistic in combination with observations of sensitivity revealed the following lab rankings in order of decreasing accuracy and precision:

low EPA reference - $1 \simeq 4,2,3$

high EPA reference - 3,4 $\simeq 2,1$

6. Contamination of low level aqueous samples exists overall for $\mathrm{Zn}$ and for individual labs for $\mathrm{Cu}(\# 3)$, $\mathrm{Mn}(\# 2)$, and $\mathrm{Cr}(\# 4)$. The source of the $\mathrm{Zn}$ may be both in sample preparation and analytical techniques. The sources of $\mathrm{Cu}, \mathrm{Mn}$ and $\mathrm{Cr}$ contamination are suspected of being in analytical techniques.

7. For natural aqueous samples containing very low concentrations of $\mathrm{Cu}$, $\mathrm{Pb}, \mathrm{Cr}, \mathrm{Zn}, \mathrm{Mn}$, and $\mathrm{Cd}$, such as spring and stream waters from WBW, the graphite furnace atomic absorption method is sufficiently sensitive to quantitatively detect concentrations without preconcentration but may be too imprecise for some trace metals to detect small natural variations (on the order of 20-50\%) in concentrations. 
Appendix A. Results of interlaboratory comparison of analysis of $2 x$ distilled water ${ }^{1}$ with $1.5 \mathrm{ml} 16 \mathrm{~N}$ Ultrex $\mathrm{HNO}_{3} /$ liter. Decimal significance as reported by each laboratory. Concentration in $\mu \mathrm{g} / 1 \mathrm{iter}$.

\begin{tabular}{rrrrrrr}
\hline $\begin{array}{c}\text { Analytical } \\
\text { Laboratory }\end{array}$ & Copper & Lead & Manganese & Zinc & Chromium & Cadmium \\
\hline 1 & 0.11 & 0.15 & 0.07 & 4.1 & 0.07 & 0.04 \\
1 & 0.11 & 0.26 & 0.11 & 13.6 & 0.07 & 0.04 \\
1 & 0.11 & 0.18 & 0.09 & 1.2 & 0.06 & 0.04 \\
2 & $<0.1$ & 0.3 & 5.8 & 2.4 & $<0.1$ & 0.04 \\
2 & 0.1 & 0.1 & 0.1 & 1.4 & 0.3 & 0.02 \\
2 & $<0.1$ & 0.1 & 0.3 & 1.7 & 0.7 & 0.02 \\
3 & 0.8 & 0.6 & $<0.5$ & 5.5 & $<0.5$ & 0.2 \\
3 & 1.0 & 0.7 & $<0.5$ & 3.5 & $<0.5$ & $<0.2$ \\
3 & 1.9 & 0.5 & $<0.5$ & 4.4 & $<0.5$ & $<0.2$ \\
4 & $<0.3$ & $<0.5$ & $<0.5$ & $<5.0$ & $<2.4$ & $<0.1$ \\
4 & $<0.3$ & $<0.5$ & $<0.5$ & $<5.0$ & $<0.1$ & $<0.1$ \\
4 & $<0.3$ & $<0.5$ & $<0.5$ & $<5.0$ & 2.7 & $<0.1$ \\
\hline
\end{tabular}

${ }^{1}$ House distilled water from ORNL BIdg. 3017 redistilled in glass and passed through IWT Co. ion exchange cartridge. 
Appendix B. Results of interlaboratory comparison of analysis of EPA Reference Trace Metal Standarid (high reference standard) by graptite furnace AA. Decimal significance as reported by each laboratory and uncorrected for distilled water and acid blank. Concentration in $\mathrm{g} / \mathrm{liter}$.

\begin{tabular}{|c|c|c|c|c|c|c|}
\hline $\begin{array}{l}\text { Analytical } \\
\text { Laboratory }\end{array}$ & Copper & Lead & Manganese & Zinc & Chromium & Cadmium \\
\hline $\begin{array}{l}1 \\
1 \\
1\end{array}$ & $\begin{array}{l}10.6 \\
10.8 \\
10.5\end{array}$ & $\begin{array}{l}46.5 \\
47.9 \\
50.6\end{array}$ & $\begin{array}{l}14.8 \\
16.9 \\
15.6\end{array}$ & $\begin{array}{l}15.0 \\
21.0 \\
11.0\end{array}$ & $\begin{array}{l}12.2 \\
10.5 \\
12.3\end{array}$ & $\begin{array}{l}2.6 \\
2.4 \\
2.5\end{array}$ \\
\hline $\begin{array}{l}2 \\
2 \\
2\end{array}$ & $\begin{array}{l}7.0 \\
6.6 \\
6.5\end{array}$ & $\begin{array}{l}30.5 \\
29.0 \\
35.0\end{array}$ & $\begin{array}{l}14.0 \\
14.0 \\
11.5\end{array}$ & $\begin{array}{l}2.3 \\
2.6 \\
1.0\end{array}$ & $\begin{array}{r}9.5 \\
9.5 \\
10.1\end{array}$ & $\begin{array}{l}1.9 \\
1.4 \\
1.4\end{array}$ \\
\hline $\begin{array}{l}3 \\
3 \\
3 .\end{array}$ & $\begin{array}{l}9.3 \\
2.0 \\
2.6\end{array}$ & $\begin{array}{r}26.4 \\
31.0 \\
28.6\end{array}$ & $\begin{array}{l}11.4 \\
11.4 \\
11.1\end{array}$ & $\begin{array}{r}11.4 \\
16.0 \\
9.2\end{array}$ & $\begin{array}{l}10.0 \\
10.0 \\
10.0\end{array}$ & $\begin{array}{l}1.2 \\
1.1 \\
1.4\end{array}$ \\
\hline $\begin{array}{l}4 \\
4 \\
4\end{array}$ & $\begin{array}{l}8.7 \\
9.9 \\
5.2\end{array}$ & $\begin{array}{l}39 \\
40 \\
40\end{array}$ & $\begin{array}{l}14 \\
14 \\
12\end{array}$ & $\begin{array}{l}11 \\
11 \\
11\end{array}$ & $\begin{array}{r}9.6 \\
10.1 \\
10.1\end{array}$ & $\begin{array}{l}2.0 \\
1.3 \\
1.5\end{array}$ \\
\hline EPA value & 9.0 & 28 & 13 & 10 & 9.2 & 1.8 \\
\hline
\end{tabular}


Appendix C. Results of interlaboratory comparison of analysis of EPA Reference Trace Metal Standard (low reference standard). Not corrected for. distilled water and acid blank. Concentration in $\mu \mathrm{g} / \mathrm{liter}$.

\begin{tabular}{ccccccc}
\hline $\begin{array}{c}\text { Analytical } \\
\text { Laboratory }\end{array}$ & Copper & Lead & Manganese & Zinc & Chromium & Cadmium \\
\hline 1 & 0.82 & 3.9 & 1.2 & 4.0 & 1.1 & 0.18 \\
1 & 0.68 & 3.9 & 1.4 & 4.2 & 1.09 & 0.31 \\
1 & 0.67 & 3.5 & 1.4 & 2.4 & 1.3 & 0.28 \\
2 & $<0.1$ & 2.5 & 1.3 & 3.2 & 0.8 & 0.4 \\
2 & $<0.1$ & 1.7 & 0.9 & 1.4 & 0.7 & 0.2 \\
2 & $<0.1$ & 2.8 & 0.8 & 0.9 & 0.6 & 0.11 \\
3 & 1.6 & 7.7 & 1.3 & 3.3 & 2.2 & 0.2 \\
3 & 2.6 & 3.2 & 1.3 & 57.0 & 2.0 & 0.3 \\
3 & 1.4 & 4.5 & 1.3 & 3.3 & 1.7 & 0.3 \\
4 & 1.2 & 4.2 & 2 & & & \\
4 & 1.1 & 3.7 & 2.1 & 5 & 3.2 & 0.2 \\
4 & 0.8 & 4.3 & 2 & $<.3$ & 4.7 & 0.2 \\
EPA value & 0.9 & 2.8 & 1.3 & 1.0 & 0.92 & 0.18 \\
\hline
\end{tabular}


Appendix.D. Results of interlaboratory comparison of analysis of rainwater sample from Walker Branch Watershed.

\begin{tabular}{ccccccc}
\hline $\begin{array}{l}\text { Analytical } \\
\text { Laboratory }\end{array}$ & Copper & Lead & Manganese & Zinc & Chromium & Cadmium \\
\hline 1 & 6.0 & 6.3 & 11.4 & 15.4 & 1.68 & 2.5 \\
1 & 5.5 & 6.5 & 11.5 & 37.0 & 1.38 & 2.6 \\
1 & 5.0 & 6.2 & 11.2 & 22.4 & 1.87 & 2.6 \\
2 & 3.4 & 3.6 & 12.0 & 2.9 & 1.1 & 2.2 \\
2 & 3.2 & 3.4 & 12.0 & 2.9 & 1.1 & 1.7 \\
2 & 3.9 & 4.0 & 3.8 & 2.5 & 0.2 & 1.4 \\
3 & 6.5 & 8.3 & 9.2 & 20.0 & 2.0 & 2.3 \\
3 & 6.5 & 5.8 & 9.0 & 23.5 & 2.0 & 1.5 \\
3 & 6.6 & 5.4 & 9.0 & 18.0 & 1.7 & 1.1 \\
4 & 8 & 6.8 & 12 & 19 & 2.8 & 2 \\
4 & 5.9 & 6.2 & 12 & 17 & 7.8 & 1.5 \\
4 & 5.6 & 6.0 & 10 & 32 & 4.9 & 1.6 \\
\hline
\end{tabular}


Appendix E. Results of interlaboratory comparison of analysis of streamwater from Walker Branch Watershed.

\begin{tabular}{|c|c|c|c|c|c|c|}
\hline $\begin{array}{l}\text { Analytical } \\
\text { Laboratory }\end{array}$ & Copper & Lead & Manganese & Zinc & Chromium & Cadmium \\
\hline $\begin{array}{l}1 \\
1 \\
1\end{array}$ & $\begin{array}{l}0.75 \\
0.65 \\
0.7\end{array}$ & $\begin{array}{r}8.3 \\
7.6 \\
11.6\end{array}$ & $\begin{array}{l}5.0 \\
5.0 \\
4.8\end{array}$ & $\begin{array}{l}5.6 \\
5.7 \\
10\end{array}$ & $\begin{array}{l}0.27 \\
0.26 \\
0.4\end{array}$ & $\begin{array}{l}0.06 \\
0.04 \\
0.05\end{array}$ \\
\hline $\begin{array}{l}2 \\
2 \\
2\end{array}$ & $\begin{array}{l}<0.1 \\
<0.1 \\
<0.1\end{array}$ & $\begin{array}{l}3.5 \\
3.3 \\
4.0\end{array}$ & $\begin{array}{l}3.1 \\
3.1 \\
3.2\end{array}$ & $\begin{array}{l}1.6 \\
1.2 \\
0.9\end{array}$ & $\begin{array}{r}<0.1 \\
0.3 \\
0.3\end{array}$ & $\begin{array}{l}0.05 \\
0.05 \\
1.3\end{array}$ \\
\hline $\begin{array}{l}3 \\
3 \\
3\end{array}$ & $\begin{array}{l}2.1 \\
2.0 \\
1.9\end{array}$ & $\begin{array}{l}9.2 \\
8.4 \\
9.2\end{array}$ & $\begin{array}{l}4.1 \\
4.3 \\
4.4\end{array}$ & $\begin{array}{r}21.0 \\
8.3 \\
5.1\end{array}$ & $\begin{array}{r}0.9 \\
<0.5 \\
<0.5\end{array}$ & $\begin{array}{l}0.3 \\
0.3 \\
0.2\end{array}$ \\
\hline $\begin{array}{l}4 \\
4 \\
4\end{array}$ & $\begin{array}{l}0.5 \\
0.5 \\
0.6\end{array}$ & $\begin{array}{l}9.4 \\
10 \\
9.7\end{array}$ & $\begin{array}{l}8 \\
6 \\
8\end{array}$ & $\begin{array}{r}6 \\
5 \\
27\end{array}$ & $\begin{array}{r}6.3 \\
<0.1 \\
3.9\end{array}$ & $\begin{array}{l}<0.1 \\
<0.1 \\
<0.1\end{array}$ \\
\hline
\end{tabular}


ORNL/TM-5422

\section{INTERNAL DISTRIBUTION}

1-7. S. I. Auerbach

8. L. C. Bate

9. B. G. Blaylock

10. E. A. Bondietti

11-20. E. D. Copenhaver

21. L. T. Corbin

22. J. 0. Duguid

23. J. W. Elwood

24. J. Emery

25. L. D. Eyman

26-27. N. M. Ferguson

28. W. Fulkerson

29. W. F. Harris

30. G. S. Henderson

31. S. Herbes

32. S. G. Hildebrand

33. J. W. Huckabee

34. D. D. Huff

35. D. R. Jackson

36-45. S. E. Lindberg

46. J. R. Lund
47. R. J. Luxmoore

48. W. S. Lyon, Jr.

49. D. Matt

50. F. L. Moore

51. H. Postma

52. R. J. Raridon

53. D. E. Reichle

54. D. S. Shriner

55. W. D. Shults

56. T. Tamura

57. F. G. Taylor

58. D. E. Todd

59-68. R. R. Turner

69. R. I. Van Hook

70. A. P. Watson

71. D. J. Wilkes

72-73. Central Research Library

74. ORNL-Y12 Technical Library Document Reference Section

75-76. Laboratory Records Department

77. Laboratory Records, ORNL R. C.

78. ORNL Patent Office

EXTERNAL DISTRIBUTION

79. Wilson T. Walker, Stilson Laboratories, $170 \mathrm{~N}$. High St., Columbus, $\mathrm{OH} 43215$.

80. Rex Chin, Woodson-Tenent Laboratories, Inc., 345 Adams Ave., Memphis, TN 38101.

81. Environmental Trace Substances Research Center, University of Missouri-Columbia, Rural Route 3, Columbia, M0 65201.

82. Wayne Swank, Coweeta Hydrologic Laboratory, Box 601, Franklin, NC 28734 .

83. R. C. Harriss, Dept. of Oceanography, Florida State University, Tallahassee, FL 32306.

84. A. W. Andren, Water Chemistry Lab, University of Wisconsin, 660 N. Park Street, Madison, WI 53706.

85. M. Tripp, Dept. of Agricultural Chemistry, Oregon State University, Corvalitis, OR 97331 .

86. Research and Technical Support Division, ORO-ERDA.

87-113. Technical Information Center. 